\title{
Microbiological Quality of Chicken Sold in Accra and Determination of $D_{10}$-Value of $E$. coli
}

\author{
Abraham Adu-Gyamfi ${ }^{1}$, Wellington Torgby-Tetteh ${ }^{2}$, Victoria Appiah $^{2}$ \\ ${ }^{1}$ Radiation Technology Centre, Biotechnology and Nuclear Agriculture Research Institute, Ghana Atomic Energy Commission, Ac- \\ cra, Ghana; ${ }^{2}$ Department of Nuclear Agriculture and Radiation Processing, School of Nuclear and Allied Sciences, University of \\ Ghana, Legon, Ghana. \\ Email: adugyamfi21@yahoo.com
}

Received November 13 ${ }^{\text {th }}, 2012$; revised April $5^{\text {th }}, 2012$; accepted April 13 $3^{\text {th }}, 2012$

\begin{abstract}
Chicken is an excellent source of good quality protein, but it is highly susceptible to microbial contamination and often implicated in food borne disease. The microbiological quality of chicken at different retail outlets (supermarkets, local markets and farms) in Accra was investigated, and $\mathrm{D}_{10}$-values of $E$. coli in refrigerated and frozen retailed chicken was determined. The microbiological quality of chicken was studied by analyzing 27 chicken thigh samples collected from the retail outlets. $\mathrm{D}_{10}$-value of Escherichia coli was determined by using a linear regression model after gamma irradiation of inoculated chicken samples with doses of $0,150,300,450,600,750$ and $900 \mathrm{~Gy}$. Mean total viable counts for the supermarkets, local markets and farms were $6.46,6.91$ and $6.57 \log _{10} \mathrm{cfu} / \mathrm{g}$ respectively. Mean total coliform counts for the supermarkets, local markets and farms were 3.80, 3.46 and $3.14 \log _{10} \mathrm{cfu} / \mathrm{g}$ respectively and the mean $S$. aureus counts were also $2.32,2.28$ and $2.70 \log _{10} \mathrm{cfu} / \mathrm{g}$ respectively. There were no significant differences $(\mathrm{p}>0.05)$ between the mean total viable count, total coliform counts and $S$. aureus count for the supermarkets, local markets and the farms. Mean counts of $E$. coli detected at the supermarket, local markets and farms were 1.27, 2.59 and $2.74 \log _{10} \mathrm{cfu} / \mathrm{g}$ respectively. Salmonella spp. was detected in 2 out of the 27 samples. Fifty-two percent and $70 \%$ of samples respectively had total viable counts and total coliform counts within the microbial safety standards. Mean $\mathrm{D}_{10}$-values of E. coli were 0.22 and $0.32 \mathrm{kGy}$ in refrigerated and frozen chicken respectively. Presence of pathogenic bacteria in fresh chicken sold in some retail outlets in Accra was confirmed. Low $\mathrm{D}_{10}$-values of $E$. coli especially under refrigerated conditions suggest susceptibility to low dose irradiation and possibility of controlling spoilage and pathogenic microflora of fresh poultry.
\end{abstract}

Keywords: Chicken; Microbiological Quality; Irradiation; E. coli; $\mathrm{D}_{10}$-Value

\section{Introduction}

Chicken is one of the most widely used meats in the world largely because its protein is of excellent quality and contains all the essential amino acids needed by man. However, chicken is not only highly susceptible to spoilage, but also frequently implicated in the spread of foodborne illnesses. During the various stages of slaughter and processing, all potential edible tissues are subjected to contamination from a variety of sources within and outside the animal [1-3] and also from the environment, equipment and operators [4]. Over 30 genera of microorganisms including seven pathogens (Campylobacter, Salmonella, Yersinia enterocolitica, Clostridium perfringens, Listeria monocytogenes, Staphylococcus aureus, E. coli $\mathrm{O} 157: \mathrm{H} 7)$, are known to contaminate poultry products $[5,6]$. The Center for Disease Control in the United States of America has estimated that these seven pathogens are together responsible for 3.9 million foodborne illnesses and 1600 deaths each year [6]. As a result of variations in processing technology, large variations occur in the microbial loads of raw poultry meat $[7,8]$.

Since poultry meat itself offers an excellent medium for the multiplication of most bacteria, including those that are not inhibited by low temperatures, storage of processed poultry meat is vital and therefore considered only under circumstances which inhibit the multiplication of the initial load of bacteria [9]. Generally, the microbiological quality of meat products including chicken as purchased by consumers depend on factors such as the quality of the raw products and other materials used or added during processing operations to the products as extraneous contaminants; efficacy of cooking process; sanitation during processing and packaging; maintenance of adequate refrigeration from the processing to the retail level and to the consumer; and finally sanitation during handling at the retail end [10]. Marketing of chicken products is generally undertaken at different re- 
tail outlets, namely supermarkets, local markets and on farms in Accra, Ghana.

Despite efforts invested in improving hygienic procedures in the processing of poultry over the years, the product continues to be heavily contaminated with various microorganisms [11,12]. Several efforts to reduce the microbial load of chicken at various stages of production have generally been unsuccessful. Attempts to decontaminate chicken meat by the addition of chemicals to the processing water had only limited success $[13,14]$. According to the WHO $[11,12]$ the elimination of pathogenic microorganisms in poultry depends largely on the correct application of processing technologies such as pasteurization, irradiation, cooking, freezing and pickling at the industrial, retail and domestic levels. Irradiation, as a physical treatment of exposing food to ionizing radiation, has been utilized for the reduction and elimination of pathogens in foods $[15,16]$. However in order to utilize irradiation as a food processing technology, it is important to study the radiation sensitivity of contaminating microorganisms since this provides a basis for accurate estimation of inactivation doses $[17,18]$. The $\mathrm{D}_{10}$-value (decimal reduction dose) is the radiation dose required to inactivate $90 \%$ of a viable bacterial population or reduce the population by a factor of 10 . Sensitivity to irradiation varies among microbial species and is affected by the components of foods and temperature during irradiation and subsequent storage. Published data on $\mathrm{D}_{10}$-values for some foods range from $0.022 \mathrm{kGy}$ for Vibrio parahaemolyticus in freshwater fish homogenate at $24^{\circ} \mathrm{C}$ to $0.78 \mathrm{kGy}$ for Salmonella stanley in ground beef at $18^{\circ} \mathrm{C}$ $20^{\circ} \mathrm{C}$ [19-21]. There is a comparatively great range of $\mathrm{D}_{10}$-values and therefore differences in resistance to gamma radiation by various microorganisms of public health significance. Estimation of $D_{10}$-values may be incorporated into risk assessments for designing processes for reduction of microbial populations in food [22].

The objectives of the present study were:

1) To investigate the microbiological quality of chicken, at different retail outlets, namely supermarkets, local markets and on farms in Accra.

2) To determine the $D_{10}$-value (decimal reduction dose) of Escherichia coli in refrigerated and frozen retailed chicken.

\section{Materials and Methods}

\subsection{Samples}

Twenty-seven chicken thigh samples were collected from three chicken retail outlets (three supermarkets, three local markets and three farms). Each of the outlets was randomly visited three times for sampling and the samples obtained were immediately transported in an insulated ice chest with ice packs to the laboratory for micro- biological analysis.

\subsection{Inoculum and Sample Inoculation}

Generic E. coli isolated from chicken thigh samples obtained from the retail outlets was used for the $\mathrm{D}_{10}$-value determination at both refrigeration and freezing temperatures. Cultures E. coli cultures were reactivated by incubation at $37^{\circ} \mathrm{C}$ for 24 hours. The activated cultures were used to prepare E. coli inoculum which was standardized to $10^{8} \mathrm{cfu} / \mathrm{ml}$ by serial dilution. A $1 \mathrm{ml}$ suspension of the E. coli isolate was aseptically added to $10 \mathrm{~g}$ portions of chicken samples in polyethylene bags. Air was expelled from the packages and they were heatsealed. The sealed polyethylene bags were hand-massaged for $1 \mathrm{~min}$ to ensure even distribution of the inoculum. The inoculated samples were stored at $3^{\circ} \mathrm{C}-5^{\circ} \mathrm{C}$ and $-18^{\circ} \mathrm{C}$ for 24 hours to enable the microorganisms to adjust to the refrigeration and freezing temperatures respectively.

\subsection{Irradiation of Samples}

The inoculated chicken samples were treated with irradiation doses of $0,150,300,450,600,750$ and $900 \mathrm{~Gy}$ at a dose rate of between $1.151 \mathrm{kGy} / \mathrm{h}-1.089 \mathrm{kGy} / \mathrm{h}$ using a Cobalt-60 source (SLL-02, Hungary) located at the Radiation Technology Centre of the Ghana Atomic Energy Commission. The absorbed dose was confirmed by Fricke's dosimetry, which is a reference chemical dosimeter based on the chemical process of oxidation of ferrous ions $\left(\mathrm{Fe}^{2+}\right)$ in aqueous sulphuric acid solution to ferric ions by ionizing radiation.

\subsection{Microbiological Analysis}

Chicken thighs obtained from different retail outlets were microbiologically analyzed to determine the populations of indicator and pathogenic microorganisms. From each sample $10 \mathrm{~g}$ was weighed with an Electronic Balance (Mettler Toledo, Switzerland). In the case of samples inoculated with E. coli, all the $10 \mathrm{~g}$ was used. The samples were blended with $90 \mathrm{ml}$ diluents $(0.1 \%$ peptone + $0.5 \mathrm{NaCl}$ ) for $90 \mathrm{~min}$ in a Waring Blender and stirred on a mechanical shaker (Junior Orbit Shaker, Lab-Line Instruments, United States of America) for $30 \mathrm{~min}$. Total viable count was determined on Plate Count Agar (Oxoid, England). Total coliform count was determined on Violet Red Bile Agar (Oxoid, England), Staphylococcus aureus was estimated on Baird-Parker Agar (Oxoid, England) and Escherichia coli was estimated on Eosine Methlyene Blue Agar (Oxoid, England). The detection of Salmonella spp. was done using $25 \mathrm{~g}$ of sample on Xylose Lysine Deoxycholate Agar (Oxoid, England). All samples were incubated at $37^{\circ} \mathrm{C}$ for 48 hours. 
Representative colonies from the plate counts were purified by subculturing and identified using morphological characteristics and standard biochemical tests. The tests used were Gram stain, catalase, oxidase, motility, nitrate, carbohydrate fermentations, triple sugar iron, and the IMViC tests as specified by Biochemical Tests for Identification of Medical Bacteria [23]. Isolates (Salmonella and E. coli) were confirmed with API test (API 20E).

\subsection{Data and Statistical Analysis}

The means were calculated for each organism from duplicate plate counts. Microbial counts $(\mathrm{cfu} / \mathrm{g})$ were transformed into $\left(\log _{10} \mathrm{cfu} / \mathrm{g}\right)$ and means were calculated. Microbial count data were subjected to Analysis of Variance using SPSS Software (Version 16, 2007). Means that were significantly different were separated by Tukey's Pairwise Comparison. In the case of calculating the $\mathrm{D}_{10}$-value of $E$. coli, the data was subjected to regression analysis. The surviving fractions, $\log _{10}\left(N / N_{0}\right)$, of $E$. coli, was calculated and used as relative changes of their actual viable cell counts. The $D_{10}$ values were calculated by plotting $\log _{10}\left(N / N_{0}\right)$ against dose $(D)$ according to the equation $\left(D_{10}=D /\left(\log _{10} N-\log _{10} N_{\mathrm{o}}\right)\right.$ where $N_{\mathrm{o}}$ is the initial viable count; $N$ is the viable count after irradiation with dose $D ; D$ is the radiation dose [24]. The linear correlation coefficient $\left(\mathrm{r}^{2}\right)$ and the regression equations were also calculated.

\section{Results}

\subsection{Microbiological Quality of Chicken Thighs}

As shown in the results on the microbiological quality of chicken thighs (Table 1), the mean total viable count for the supermarkets, local markets and farms were 6.46, 6.91 and $6.57 \log _{10} \mathrm{cfu} / \mathrm{g}$ respectively. The mean total coliform counts for the supermarkets, local markets and farms were $3.80,3.46$ and $3.14 \log _{10} \mathrm{cfu} / \mathrm{g}$ respectively. The mean Staphylococcus aureus count were 2.32, 2.28 and $2.70 \log _{10} \mathrm{cfu} / \mathrm{g}$ for the supermarkets, local markets and farms respectively. There were no significant differences $(p>0.05)$ between the mean total viable count, total coliform counts and Staphylococcus aureus count for the supermarkets, local markets and the farms. Mean counts of $E$. coli detected at the supermarket, local markets and farms were 1.27, 2.59 and $2.74 \log _{10} \mathrm{cfu} / \mathrm{g}$ respectively. Significant differences were obtained between the mean count of $E$. coli for the supermarkets and the other outlets $(p<0.05)$. There were no differences between the means of the local markets and the farms ( $p$ $>0.05$ ). As shown in Table 1, Salmonella spp. was detected in one sample from the supermarket and one sample from the local market. All other samples recorded no Salmonella spp. Fifty-two percent $(52 \%)$ of the total samples tested had total viable counts within the microbial safety standards of $<7 \log _{10} \mathrm{cfu} / \mathrm{g}$ and $70 \%$ had total coliform counts within the microbial safety standards of $<4 \log _{10} \mathrm{cfu} / \mathrm{g}$.

\subsection{Radiation Sensitivity of $\boldsymbol{E}$. coli}

As shown in the radiation sensitivity curves (Figure 1), the decimal reduction dose $\left(\mathrm{D}_{10}\right.$-values $)$ for $E$. coli in refrigerated chicken ranged from $0.20-0.24 \mathrm{kGy}$ and the mean $\mathrm{D}_{10}$ value was $0.22 \pm 0.02 \mathrm{kGy}$ (Table 2 ). The $\mathrm{D}_{10^{-}}$ values of $E$. coli in frozen chicken ranged from $0.28-$ $0.34 \mathrm{kGy}$ (Figure 2) and the mean $\mathrm{D}_{10}$-value was $0.32 \pm$ $0.03 \mathrm{kGy}$ (Table 2). The coefficients of the regression

Table 1. Microbiological quality of chicken thighs at different retail outlets in Accra.

\begin{tabular}{cccccc}
\hline RETAIL OUTLET & Total Viable Count & Total Coliform Count & S. aureus Count & E. coli Count & Detection of Salmonella sp \\
\hline \multirow{2}{*}{ Supermarkets } & $6.46 \pm 0.95^{\mathrm{a}}$ & $3.80 \pm 0.82^{\mathrm{a}}$ & $2.32 \pm 0.94^{\mathrm{a}}$ & $1.27 \pm 1.55^{\mathrm{a}}$ & $1^{*}$ \\
& $(4.80-7.60)$ & $(2.60-4.90)$ & $(0-3.15)$ & $(0.00-3.45)$ & $9^{* *}$ \\
\multirow{2}{*}{ Local markets } & $6.91 \pm 0.82^{\mathrm{a}}$ & $3.46 \pm 0.97^{\mathrm{a}}$ & $2.28 \pm 0.98^{\mathrm{a}}$ & $2.59 \pm 1.08^{\mathrm{b}}$ & 1 \\
& $(5.30-8.30)$ & $(2.30-5.50)$ & $(0-3.34)$ & $(0.00-3.56)$ & 9 \\
Farms & $6.57 \pm 1.07^{\mathrm{a}}$ & $3.14 \pm 0.84^{\mathrm{a}}$ & $2.70 \pm 0.40^{\mathrm{a}}$ & $2.74 \pm 0.38^{\mathrm{b}}$ & ND \\
& $(5.00-8.90)$ & $(2.40-5.00)$ & $(2.20-3.08)$ & $(2.08-3.10)$ & 9 \\
\hline
\end{tabular}

Values are $\log _{10}($ mean cfu $/ \mathrm{g}) \pm \mathrm{SD}$; Means with the same letters in a column are not significantly different (p $\left.>0.05\right)$; Values in brackets represent range for nine replicates; ${ }^{*}$ No of samples showing detection; ${ }^{* *}$ Total number of Samples tested; ND = Not detected.

Table 2. Mean $D_{10}$-values of $E$. coli on refrigerated and frozen chicken.

\begin{tabular}{cccc}
\hline Substrate & Regression equation & $\mathrm{r}^{2}$ & $\mathrm{D}_{10}$ value $(\mathrm{kGy})^{\mathrm{a}}$ \\
\hline Refrigerated chicken & $\mathrm{Y}=-4.55 \mathrm{X}-0.423$ & 0.966 & $0.22 \pm 0.02$ \\
Frozen chicken & $\mathrm{Y}=-3.18 \mathrm{X}-0.099$ & 0.972 & $0.32 \pm 0.03$ \\
\hline
\end{tabular}

${ }^{\mathrm{a}}$ Mean \pm SD of three replicate each. 


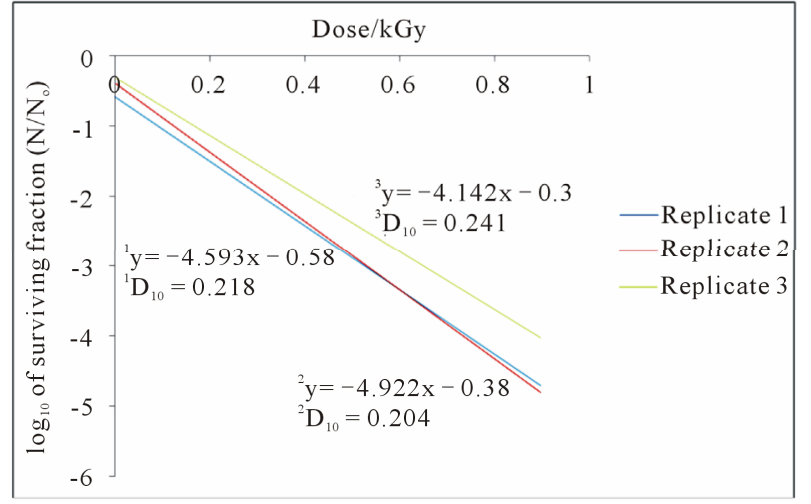

Figure 1. Radiation sensitivity curves of Escherichia coli in refrigerated chicken.

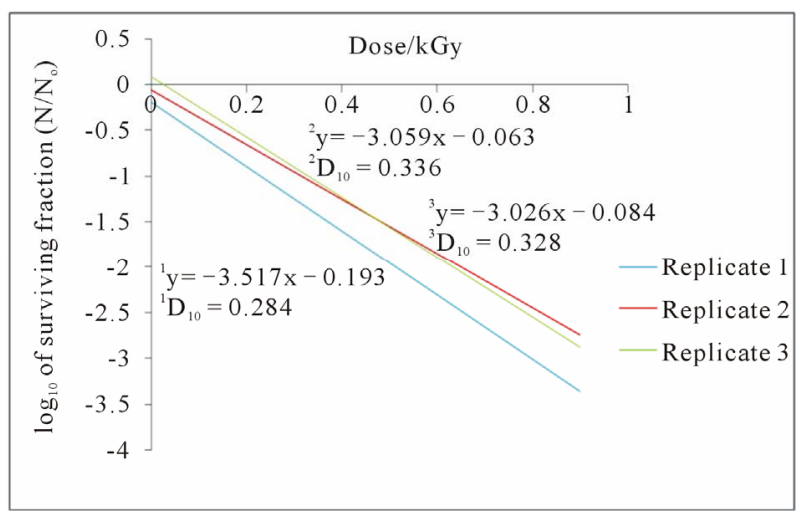

Figure 2. Radiation sensitivity curves of Escherichia coli in frozen chicken.

line were all $>0.90$, indicating a strong negative linear correlation.

\section{Discussion}

Retailing of chicken in Accra is mainly undertaken at supermarkets, local markets and on farms. Generally, hygienic conditions in supermarkets are better those in local markets and farms, however the current study has revealed no significant differences $(p>0.05)$ between the mean total viable count, total coliform counts and Staphylococcus aureus counts for the supermarkets, local markets and the farms. This observation could be largely due to the use of improved storage methods such as freezing at most retail outlets irrespective of the prevailing general practice of hygiene. Total viable count is indicative of the populations of spoilage microorganisms and act as an index of hygienic quality. The mean total viable counts are comparable to the values $6.64-6.91$ $\log _{10} \mathrm{cfu} / \mathrm{g}$ [25] but higher than the $4.46 \log _{10} \mathrm{cfu} / \mathrm{g}$ [26] and $4.52 \log _{10} \mathrm{cfu} / \mathrm{g}$ [10] reported for chicken in other studies.

The mean counts are also higher than the range of $8 \times$ $10^{4}$ to $6 \times 10^{6} \mathrm{cfu} / \mathrm{g}$ obtained for total aerobic bacteria of chicken meat in several different areas of Japan [27]. In this study, $48 \%$ of the samples from the 3 retail outlets had unacceptable total viable counts, according to domestic and international standards [28,29]. This finding confirms the existence of microbial hazards. Although the mean total coliform counts were low for all the retail outlets compared to other similar studies [30], $30 \%$ of the samples had unacceptable counts according to domestic and international standards. High total coliform counts are usually associated with significant levels of enteric pathogens [31].

The counts of Staphylococcus aureus were high especially for local markets and farms in relations to domestic and international standards. The reason for this could be poor personal hygiene of workers and the technique used in eviscerating the chicken carcasses. In the case of $E$. coli, all the samples did not meet local standards of zero tolerance for fresh chicken. Even though only generic $E$. coli was enumerated, this finding is worrying considering the fact that this faecal coliform is an indicator of sanitary conditions. The presence of $E$. coli in some of the chicken samples may be as a result of contamination from the environment and personnel or from the materials used for processing including water. The detection of Salmonella spp. in some of the samples raises issues of food safety and the prevalence of $7.41 \%$ reported in this study compares with the prevalence of $5.7 \%$ reported in a study of chicken carcasses in Accra [32].

This study has revealed the existence of microbial hazards related to the retailing of fresh chicken in Accra. It is therefore necessary to explore the use of an innovative food processing technology such as irradiation in addition to traditional temperature management techniques such as chilling and freezing. In particular, the technology of irradiation has been recognized as one of the safest and most effective methods for inactivating bacteria in raw poultry either freshly chilled or frozen $[20,33]$. The study has investigated the radiation sensitivity of $E$. coli and confirmed the possibility of its elimination from both refrigerated and frozen chicken. The respective $D_{10}$-values of 0.22 and $0.32 \mathrm{kGy}$ obtained for refrigerated and frozen chicken in this study are quite comparable to the values of 0.27 and $0.42 \mathrm{kGy}$ reported for E. coli $0157: \mathrm{H} 7$ in mechanically deboned chicken irradiated at 5 and $-5^{\circ} \mathrm{C}$ [34]; and also the reported range of 0.16 to 0.39 $\mathrm{kGy}$ on poultry meat $[35,36]$ as well as the value of 0.25 $k G y$ on minced chicken [37]. Considering the $\mathrm{D}_{10}$-values and the counts of $E$. coli from the retail outlets suggest that irradiation doses of $3 \mathrm{kGy}$ could result in more than $9 \log$ cycle reduction. The $\mathrm{D}_{10}$-values reported in this study for E. coli in frozen chicken is however below other values reported for E. coli type 1 [38] and a nonpathogenic strain of E. coli [39]. The differences in $\mathrm{D}_{10}$-values estimated in this study and others cited above 
may be due to probable differences in the strain of $E$. coli isolate, substrate and other experimental conditions.

It is important to note the $\mathrm{D}_{10}$-value for $E$. coli was higher under frozen than refrigerated conditions in the current study as was also reported by Thayer and Boyd [34]. In a similar study [40], it was also revealed that $E$. coli $0157: \mathrm{H} 7$ had a significantly higher $\mathrm{D}_{10}$-value when irradiated at $-17^{\circ} \mathrm{C}$ to $-15^{\circ} \mathrm{C}$ than when irradiated at $3^{\circ} \mathrm{C}$ to $5^{\circ} \mathrm{C}$. The protective effect of low temperatures during irradiation may be attributed to reactive intermediates, primarily $\mathrm{OH}$ radicals that result from the hydrolysis of water. Freezing immobilizes water molecules, and as a consequence, the diffusion of free radicals is restricted [41]. In addition the mobility of free radicals is limited under conditions of limited free water as in dry or frozen foods, thus increasing the likelihood of the radicals undergoing self-quenching rather than damaging nearby bacterial cells.

\section{Conclusion}

The study has generally confirmed the presence of pathogenic bacteria of public health importance in fresh chicken sold in some retail outlets in Accra. The calculated low $\mathrm{D}_{10}$-values of $E$. coli especially under refrigerated conditions suggest susceptibility to low dose irradiation and the possibility of controlling spoilage and pathogenic microflora of fresh poultry. This finding is significant for the poultry industry in Ghana which can employ the technology of radiation processing to improve the hygienic quality of chicken and other poultry products.

\section{REFERENCES}

[1] L. Kozacinski, M. Hadaziosmanovic and N. Zdolec, "Microbiological Quality of Poultry Meat on the Croatian Market," Veterinarski Arhiv, Vol. 76, No. 14, 2006, pp. 305-313.

[2] E. Borch and P. Arinder, "Bacteriological Safety Issues in Beef and Ready-to-Eat Meat Products, as well as Montrol Measures," Meat Science, Vol. 62, No. 3, 2002, pp. 381390. doi:10.1016/S0309-1740(02)00125-0

[3] M. Alvarez-Astorga, R. Capita, C. Alonso-Callega, B. Moreno and M. Del Camoni Garcia Fernaudez, "Micro-Biological Quality of Retail Chicken in By-Products in Spain," Meat Science, Vol. 62, 2002, pp. 45-50. doi:10.1016/S0309-1740(01)00225-X

[4] G. C. Mead, "Hygiene Problems and Control Process Con-Tamination," In: G. C. Mead, Ed., Processing of Meat, Elsevier Science Publishers Ltd., New York, 1989, pp. 183-220.

[5] International Atomic Energy Agency (IAEA), "Irradiation of Poultry Meat and Its Products," IAEA-TECDOC-688, Vienna, 1993.

[6] P. S. Mead, L. Slutsker, V. Dietz, L. F. McCaig, J. S. Bresee, C. Shapiro, P. M. Griffin and R. V. Tauxe,
"Food-Related Illness and Death in the United States," Emerging Infectious Diseases, Vol. 5, No. 5, 1999, pp. 607-625. doi:10.3201/eid0505.990502

[7] I. Klinger, H. Welgreen and D. Basker, "Microbiological Contamination of Fresh Broiler Chicken Meat in a Market," Refuah Veterinary, Vol. 37, 1980, pp. 97-101.

[8] I. Klinger, V. Fuchs, D. Basker, E. Malenky, G. Barkat and N. Egoz, "Microbiological Quality of Industrially Processed Frozen Broiler Chickens in Israel," Refuah Veterinary, Vol. 38, 1981, pp. 136-148.

[9] R. Blankenship, "Reduction of Spoilage and Pathogenic Bacteria," Broiler Industry, Vol. 24, 1986.

[10] P. R. Selvan, B. Narendra, S. Sureshkumar and V. Venkatamanujam, "Microbial Quality of Retail Meat Products Available in Chennai City," American Journal of Food Technology, Vol. 2, No. 1, 2007, pp. 55-59. doi:10.3923/ajft.2007.55.59

[11] World Health Organisation (WHO), "Prevention and Control of Foodborne Salmonellosis through the Application of the Hazard Analysis Critical Control Point System," Report of an International Commission on Microbiological Specification for Foods (ICMSF), WHO/CDS/ VPH/86. 65, Geneva, 1986.

[12] World Health Organisation (WHO), "Health Surveillance and Management Procedures for Food Handling Personnel," Technical Report Series No. 785, WHO, Geneva, 1989.

[13] B. W. Sheldon and L. A. Brown, "Efficacy of Ozone as a Disinfectant for Poultry Carcasses and Chill Water," Journal of Food Science, Vol. 51, No. 2, 1986, pp. 305309. doi:10.1111/j.1365-2621.1986.tb11116.x

[14] J. M. Frels, K. J. Samuelson, G. W. Froning and J. H. Rupnow, "Evaluation of Glucose Oxidase-Catalase Treatment to Improve the Microbiological Quality of Poultry Meat," Poultry Science, Vol. 63, 1988, pp. 841- 843

[15] J. Farkas, "Irradiation for Better Foods," Trends in Food Science and Technology, Vol. 17, No. 4, 2006, pp. 148152. doi:10.1016/j.tifs.2005.12.003

[16] International Consultative Group on Food Irradiation (ICGFI), "Enhancing Food Safety through Irradiation," International Consultative Group on Food Irradiation, FAO/IAEA, Vienna, 1999.

[17] A. Adu-Gyamfi, J. Nketsiah-Tabiri and R. Boatin, "Determination of $\mathrm{D}_{10}$ Values of Single and Mixed Cultures of Bacteria after Gamma Irradiation," Journal of Applied Science and Technology, Vol. 14, No. 1-2, 2009, pp. 1318. doi:10.4314/jast.v14i1-2.44317

[18] D. W. Thayer, "Sources of Variation and Uncertainty in the Estimation of Radiation $\mathrm{D}_{10}$ Values for Foodborne Pathogens," ORACBA News, Vol. 4, No. 5, 2000.

[19] J. D. Monk, L. R. Beuchat and M. P. Doyle, "Irradiation Inactivation of Food-Borne Microorganisms," Journal of Food Protection, Vol. 58, No. 2, 1995, pp. 197-208.

[20] J. Farkas, "Irradiation as a Method for Decontaminating Food," International Journal of Food Microbiology, Vol. 44, No. 3, 1998, pp. 189-204. doi:10.1016/S0168-1605(98)00132-9 
[21] S. D. Gamage, N. G. Faith, J. B. Luchansky, D. R. Buege, and S. C. Ingham, "Inhibition of Microbial Growth in Chub-Packed Ground Beef by Refrigeration $\left(2^{\circ} \mathrm{C}\right)$ and Medium-Dose (2.2 to $2.4 \mathrm{kGy}$ ) Irradiation," International Journal of Food Microbiology, Vol. 37, No. 2-3, 1997, pp. 175-182. doi:10.1016/S0168-1605(97)00073-1

[22] M. Cheroutre-Vialette and A. Lebert, "Growth of Listeria monocytogenes as a Function of Dynamic Environment at $10^{\circ} \mathrm{C}$ and Accuracy of Growth Prediction with Available Models," Food Microbiology, Vol. 71, No. 5, 2000, pp. 83-92. doi:10.1006/fmic.1999.0290

[23] J. F. Macfaddin, "Biochemical Tests for Identification of Medical Bacteria," Williams and Wilkins, Baltimore, 1980, pp. 173-183.

[24] C. R. Stumbo, J. R. Murphy and J. Cochran, "Nature of Death Time Curves of PA 3679 and Clostridium botulinum," Food Technology, Vol. 4, 1950, pp. 292-302.

[25] A. Amara, M. Badoum, M. Faid and K. Bouzoubaa, "Microbial Contamination of Poultry Slaughtered in Traditional Shops in Morocco," Microbiologique, Aliments et Nutrition, Vol. 12, 1994, pp. 323-327.

[26] B. Oumokhtar, "Bacteriological Quality of Slaughtered Animals for the Preparation of Commercialised Canned Meat at Rabat," National Doctoral Thesis, Faculty of Sciences, University of Chouaib Doukkali, El Jadida, 2000.

[27] Y. Prachasitthisak, D. Banati and H. Ito, "Shelf Life Extension of Chicken Meat by $\gamma$-Irradiation and Microflora Changes," Food Science and Technology International, Vol. 2, No.4, 1996, pp. 242-245.

[28] Ghana Standards, Ref. Nos GS 235:1997, GS 236:1997, Ghana Standards Board, 1997.

[29] International Commission on Microbiological Specifications for Foods (ICMSF), "Microorganisms in Foods 5, Microbiological Specifications of Food Pathogens," In: T. A. Roberts, A. C. Baird-Parker and R. B. Tompkin, Eds., International Commission on Microbiological Specifications for Foods, Blackie Academic and Professional, London, 1996.

[30] A. Chaiba, F. F. Rhazi, A. Chahloaui, B. R. Soulaymani and M. Zerhouni, "Microbiological Quality of Poultry Meat on the Mekne's Market (Morocco)," Internet Journal of Food Safety, Vol. 9, 2007, pp. 67-71.

[31] W. G. Eisel, R. H. Linton and P. M. Muriana, "A Survey of Microbial Levels for Incoming Raw Beef in a Processing Plant," Food Microbiology, Vol. 14, No. 3, 1997, pp. 273-282. doi:10.1006/fmic.1996.0094
[32] B. A. Sackey, P. Mensah, E. Collison and E. S. Dawson, "Campylobacter, Salmonella, Shigella and Escherichia coli in Live and Dressed Poultry from Metropolitan Accra," International Journal of Food Microbiology, Vol. 71, No. 1, 2001, pp. 21-28. doi:10.1016/S0168-1605(01)00595-5

[33] International Consultative Group on Food Irradiation (ICGFI), "Enhancing Food Safety through Irradiation, International Consultative Group on Food Irradiation," FAO/IAEA, Vienna, 1999.

[34] D. W. Thayer and G. Boyd, "Elimination of Escherichia coli $\mathrm{O} 157: \mathrm{H} 7$ in Meats by Gamma Irradiation," Applied Environmental Microbiology, Vol. 54, No. 4, 1993, pp. 1030-1034.

[35] D. W. Thayer, G. Boyd, J. B. Fox Jr., L. Lakritz and J. W. Hampson, "Variations in Radiation Sensitivity of Foodborne Pathogens Associated with Suspending Meat," Journal of Food Science, Vol. 60, No. 1, 1995, pp. 63-67. doi:10.1111/j.1365-2621.1995.tb05607.x

[36] M. Patterson, "Sensitivity of Bacteria to Irradiation on Poultry Meat under Various Atmospheres," Letters in Applied Microbiology, Vol. 7, 1998, pp. 55-58. doi:10.1111/j.1472-765X.1988.tb01251.x

[37] A. Adu-Gyamfi, J. Nketsiah-Tabiri and F. Apea Bah "Radiosensitivities of Bacterial Isolates on Minced Chicken and Poached Chicken Meal and Their Elimination Following Irradiation and Chilled Storage," Radiation Physics and Chemistry, Vol. 77, No. 2, 2008, pp. 174178. doi:10.1016/j.radphyschem.2007.04.001

[38] D. O. Halkman and H. B. An, "Death Kinetics of E. coli O157:H7, E. coli and Natural Contaminant Coliforms in Minced during Irradiation Treatment and Storage," Turkish Journal of. Veterinary Animal Science, Vol. 28, 2004, pp. 915-920.

[39] E. Mayer-Miebach, M. R. Stahl, U. Eschrig, L. Deniaud, D. A. E. Ehlerman and H. P. Schuchman, "Inactivation of Non-Pathogenic Strain of E. coli by Ionizing Radiation," Food Control, Vol. 16, 2005, pp. 701-705. doi:10.1016/j.foodcont.2004.06.007

[40] M. R. Clavero, J. D. Monk, L. R. Beuchat, M. P. Doyle and P. Brakett, "Inactivation of Escherichia coli O157:H7, Salmonella, and Campylobacter jejuni in Raw Ground Beef by Gamma Irradiation," Applied Environmental Microbiology, Vol. 60, No. 6, 1994, pp. 2068-2075.

[41] J. F. Diehl, “Biological Effects of Ionizing Radiation,” In: J. F. Diehl, Ed., Safety of Irradiated Foods, Marcel Dekker Inc., New York, 1990, pp. 95-136. 